\title{
Lemmel's Syndrome: A Rare Cause of Cholestasis
}

\section{Síndrome de Lemmel: Uma Causa Rara de Colestase}

João CRUZ1 ${ }^{1}$, António P. MATOS ${ }^{1}$, Miguel RAMALHO $\rrbracket^{1}$

Acta Med Port 2018 Apr;31(4):228-228 - https://doi.org/10.20344/amp.8831

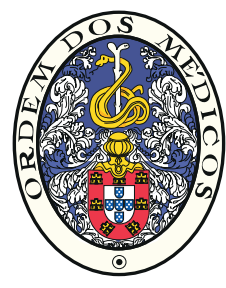

Keywords: Cholestasis/etiology; Diverticulum/complications; Duodenal Diseases/complications

Palavras-chave: Colestase/etiologia; Divertículo/complicações; Duodenopatias/complicações

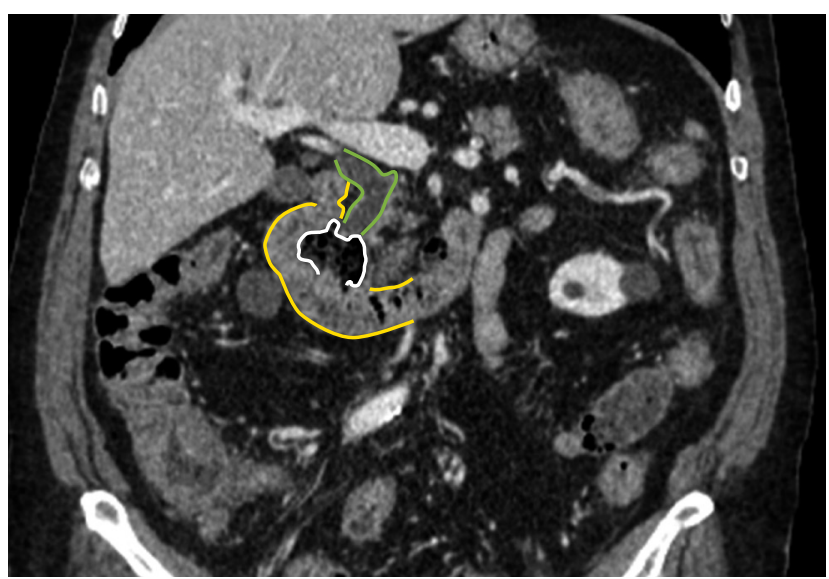

Figure 1 - Coronal reformat of contrast-enhanced CT shows the presence of a diverticulum ( $38 \times 24 \mathrm{~mm}$, white line) in the second portion of the duodenum (yellow lines) and common bile duct dilation (green lines). The duodenal diverticulum is well depicted as a gas-containing sac protruding from the inner wall of the duodenum.

A 72-year-old male was admitted with infectious colitis. Laboratory tests revealed enzyme elevation with a cholestatic hepatitis pattern [total-bilirubin: $2.5 \mathrm{mg} / \mathrm{dL}(<1.2 \mathrm{mg} /$ $\mathrm{dL}$ ), direct-bilirubin: $1.42 \mathrm{mg} / \mathrm{dL}(<0.3 \mathrm{mg} / \mathrm{dL})$ AST: $460 \mathrm{IU} / \mathrm{L}$ (< $40 \mathrm{IU} / \mathrm{L}), \mathrm{ALT}: 467 \mathrm{IU} / \mathrm{L}$ (< $50 \mathrm{IU} / \mathrm{L}), \mathrm{GGT}: 977 \mathrm{IU} / \mathrm{L}(<60$ IU/L)], which persisted after patient discharge. Computed tomography (CT) showed a duodenal diverticulum of the second part of duodenum and dilation of the biliary tree, with no evidence of pancreatic lesions (Fig.1). A magnetic resonance imaging study, which included a cholangiographic sequence, (Fig. 2) confirmed the duodenal diverticulum and biliary dilation. Endoscopic ultrasonography (EUS) was

\section{PROTECTION OF HUMANS AND ANIMALS}

The authors declare that the procedures were followed according to the regulations established by the Clinical Research and Ethics Committee and to the Helsinki Declaration of the World Medical Association.

\section{DATA CONFIDENTIALITY}

The authors declare having followed the protocols in use at their working center regarding patients' data publication.

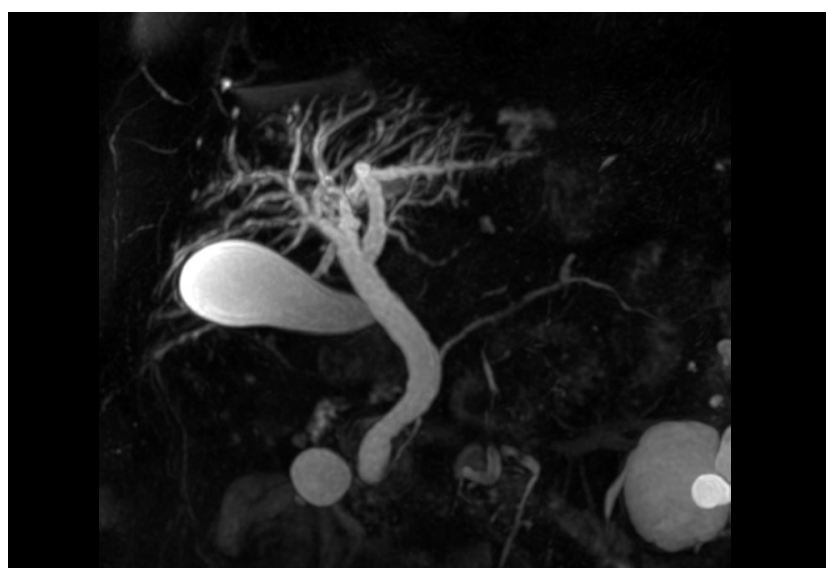

Figure $2-3 D$ MIP MRCP showing dilation of intra-hepatic and extra-hepatic bile ducts with caliber transition at the distal part of the common bile duct adjacent to the pancreatic papilla, with no evidence of intraductal stones or dilation of the main pancreatic duct. The duodenal diverticulum is not depicted in this sequence due to its low fluid-content.

performed to exclude peri-ampullary tumor. The biopsy did not reveal tumor cells. A diagnostic of Lemmel's syndrome (i.e., juxtampullary duodenal diverticulum compressing the intrapancreatic bile duct resulting in obstructive jaundice in the absence of cholelithiasis or other detectable obstacles) was done.

Duodenum diverticula are most frequently asymptomatic. ${ }^{1,2}$ Lemmel's syndrome was first described in $1934,{ }^{3}$ but to date, very few cases have been published. The diagnosis is confirmed by imaging, including barium meal, EUS, endoscopic retrograde cholangiopancreatography, CT or magnetic resonance cholangiopancreatography. ${ }^{4,5}$

\section{PATIENT CONSENT}

\section{Obtained.}

\section{CONFLICTS OF INTEREST}

All authors report no conflict of interest.

\section{FUNDING SOURCES}

This research received no specific grant from any funding agency in the public, commercial, or not-for-profit sectors.

\section{REFERENCES}

1. Rizwan MM, Singh H, Chandar VP, Zulfiqar M, Singh V. Duodenal diverticulum and associated pancreatitis: case report with brief review of literature. World J Gastrointest Endosc. 2011;3:62-3.

2. Sutherland T, Galvin A, Little AF. CT characterisation of pancreatic neoplasm: tumour mimics. Insights Imaging. 2011;2:389-97.

3. Kang HS, Hyun JJ, Kim SY, Jung SW, Koo JS, Yim HJ, et al. Lemmel's syndrome, an unusual cause of abdominal pain and jaundice by impacted intradiverticular enterolith: case report. J Korean Med Sci. 2014;29:874-8.

4. Lemmel G. Die klinische bedeutung der duodenaldivertikel. Arch Verkrcht. 1934;56:59-70.

5. Rouet J, Gaujoux S, Ronot M, Palazzo M, Cauchy F, Vilgrain V, et al. Lemmel's syndrome as a rare cause of obstructive jaundice. Clin Res Hepatol Gastroenterol. 2012;36:628-31.

1. Department of Radiology. Hospital Garcia de Orta. Almada. Portugal.

$\triangle$ Autor correspondente: Miguel Ramalho. miguel-ramalho@netcabo.pt

Recebido: 10 de fevereiro de 2017 - Aceite: 27 de março de 2018| Copyright @ Ordem dos Médicos 2018 